\title{
Study on the Financial Integration after the Merger and Acquisition
}

\author{
Li Sheng \\ Management School, Wuhan University of Science and Technology \\ Wuhan, China 430081 \\ Lisheng@wust.edu.cn
}

Keywords: Mergers and acquisitions; Integration; Financial system; Stakeholder; Strategy

\begin{abstract}
With the all-round development of social productive forces and technological progress, deepening of economic globalization, merger and acquisition continues to expand its scale. Changing merger forms has made the merger and acquisition become a common economic behavior.And it has become an important mode of capital operation in enterprise, as well as reallocation of resources for community, an effective way to improve efficiency for resources use. Because of the current low success rate of mergers and acquisitions, as a key part of the integration process and the core content, financial integration has become an urgent subject of studying and deepening. This paper is based on this background, summarize the content of financial integration after merger and acquisition. Mergers and acquisitions will carry out a full range of enterprise resources integration. Financial issues exist in the whole process of merger and acquisition activity. Finally it will effect survival of the enterprise.
\end{abstract}

\section{Introduction}

The success of financial integration determine the success and failure of the merger and acquisition activity to a large extent. Currently there is a trend that the process of the $\mathrm{M} \& \mathrm{~A}$ is emphasized instead of the integration. This causes the purposes of increasing the enterprise value of merger and acquisition cannot be fully realized. So, studying the integration after enterprises mergers and acquisitions is very urgent. As a basic integration in merger and acquisition, financial integration is the core of the integration process and an important part. It is also the effective assurance to achieve "financial synergies". Therefore, financial integration must be taken into account in the process of mergers and expansion, through effective financial integration to realize its expansion strategy.

\section{Integration of enterprise's objective of financial management}

Financial management is mainly dealing with financial relations and organizing financial activities. It is generally called financing activities. On the one hand its objective is through various financial activities of enterprise management services required to meet pre-set standards. It is the logical starting point of financial management, as well as the basic criterion for assessing whether financing activities is reasonable. On the other hand, the objectives of financial management is the logical starting point of study on theory framework of financial. Research on the financial theory is carried out closely around this objective, and it is an important issue of financial theory, is also a non-negligible financial practice problem. Academia for financial management fields has in-depth researching on financial objective, which including economic profit maximization, and profit maximization, and net present value maximization, and capital cost minimum, and shareholders wealth maximization, and enterprise value maximization, and Enterprise stakeholder wealth maximization. In different times enterprises may have different financial management objectives; in the same times different enterprises may have different financial management objectives. Financial management objectives may be profit maximization for some enterprises, some may be stakeholder wealth maximization. 


\section{The integration of financial management system}

The integration of financial institution. Financial institution of an enterprise is a functional department that it can check and supervise the economic activities of the enterprise in order to promote the strengthening the functions of management and increase economic benefits of enterprises. Their main responsibility is to formulate financial budget or financial projections, plans, raise funds, analyze and assess the feasibility of the project, preparation of the investment management of the capital budget, responsible for the company's cash and marketable securities, analyze customer credit ratings, formulating credit policies, accounts receivable policy, responsible for the distribution of profit policy formulation and implementation, and analysis of the enterprise's financial position and other functions. Due to both parties of merger and acquisition may be in different industry, and may have different ways of management and operation, the institution in financial management may be differ. So the new financial institution should be immediately re-established through adjust both parties financial institution after the merger and acquisition, to enable enterprises to rapidly enter the normal production and operation status.

The new financial institution should be set according to the operational characteristics of enterprise and business settings, and then break down its financial functions. The achievement of merger objectives must ultimately rely on institutions to execute, such institutions have a certain structure, through a body with such a structure to carry out its functions. Each post should also be taken into account by financial institutions and everyone should have a clear division of responsibilities, and the ability to hold each other up, so as to effectively prevent the occurrence of fraud and error. Cashiers and other accounting positions are set respectively in the actual setting, served by hand, reflecting the "account is in charge of the money" principle. In addition, the ultimate goal of the setting of financial institutions is to efficiently accomplish a given objective, which requires all staff carry out their duties, coordinated financial sector, avoid duplication of duties or agency and an oversupply.

The integration of financial management system. The financial management system is a set of rules that staff should obey in the working process of the financial management of the organization. It is the code of conduct of people engaging in financial activities, with hard binding. The working of financial management after the merger must be carried out on the premise that enterprise must have a sound and proper financial management system. Due to both parties of mergers and acquisitions affiliate to different stakeholders' entities before the merger, each party is from its own corporate goals as a starting point, developing financial management system suitable for their own development. After the merger, the new enterprise must establish a set of unified financial management system subject to the merger of enterprise group's goal as a starting point.

Financial human resources integration. Talent competition has become the focus of business competition. So after the takeover, how to retain their best talent of the target enterprise, it is not only the competition for the enterprise, but also wisdom contest. Redundancy is also a key link in staff restructuring after merger while retaining good employees, although it may encounter a lot of obstacles. For the financial sector the staffing issues need to be addressed after the merger is completed. That is, how to integrate financial human resources of the enterprises of the two parties. The acquired enterprise would involve reallocation of financial personnel issues, this situation must be considered according to different persons. In General, highly qualified and experienced finance professionals can create value for enterprises, with a focus on retaining this talent. When both parties are in different industries, possibly corporate finance personnel of the merger are unfamiliar with the new industry's business, and the acquired company's finance staff are already familiar with this type of business, they can able to do the work, then you can retain, or you need to replace some of the officers.

\section{The integration of main financial activities}

The enterprise's main economic activities include financing activities, investment activities and operation activities. Correspondingly, there are financing management, the investment management, 
working capital management and dividend distribution, and so on. Below are the elaboration for merger integration of financial management of these activities.

The integration of financing management. Financing activity is the primary function of the company's financial management. Through mergers and acquisitions, Companies gradually expand the scale and its management must adhere to a comprehensive view of financing, the goal is to achieve long term sustainable development for the enterprise group. The development of financial markets and derivative financial instruments makes the trend of diversified financing channels. But in general the financial resources can be divided into two broad categories: the external financing and internal financing. External funding is mainly through domestic capital markets and international capital markets to raise funds, internal financing is primarily raise money from business groups, such as between parent companies and subsidiaries of financial intermediation, financial intermediation between affiliates and subsidiaries, or make full use of the retained earnings of the enterprise. Enterprise can combine internal and external financing, in a way, to achieve optimum capital composition. Then the enterprise has the lowest cost of financing, the minimal financial risk, the lowest enterprise's tax level.

The integration of investment management. Investing is about to configure the raised money in a certain project or area in the hope of future to reap the benefits, or it is about to put the raised money in the enterprises and financial markets at home and abroad in order to secure future earnings. Investment management is an important element of enterprise group's financial activities after the merger and acquisition, so it is essential to establish scientific investment management policies to guide investment management.

Parent company of enterprise groups can exercise control over the investing activities of merged subsidiary company by capital budget management. Capital budget has the characteristics of comprehensive planning and dynamic controlling. Through this method, the parent company may take appropriate standards of capital budgeting to evaluate the subsidiary's investment income, appraise the degree of capital budgeting goals, and provide a basis for the formulation of the budget for the next year. Capital budgeting projects often involved in spending a lot of money, it will have a longer effect for multinational corporations. Parent companies must pay attention to the preparation and implementation of capital budgeting decisions. In the preparation process of capital budgeting, agency costs can be reduced if board of directors or managers participate in the preparation process. Studies have shown that, during the budget implementation process, "participation" is pre-conditions of "Pareto optimal". This is because the boards of subsidiary companies or executives were directly involved in the drafting of the budget which will enable the agent (refer to the boards of subsidiary companies or executives) and the principal (parent company) exchange the information.

Integration of working capital management. The working capital management for enterprise groups usually refers to the net working capital, which is the difference between current assets and current liabilities. So the management of working capital includes both current asset management and management of current liabilities. Current assets are divided into two parts: temporary current assets and permanent current assets. Permanent current assets have the characters of long-term assets on the financing needs, that is, through funds circulating and working capital cycle, the funding has long been occupied correspondingly. Temporary current assets are due to seasonal products production and sale, it is the temporary demand for funds.

According to the different reimbursement time, there are short-term and long-term financing. In the short-term financing there is a portion of financing which is naturally financed without enterprise special arrangement. And with the continuation of the business, these part of funding is long-standing. They have the properties of long-term capital. Therefore, there can also be said to have three ways to provide money for corporate current assets, namely, natural financing, short-term financing and long-term financing of human nature. How to identify the percentage of every financing methods in total funding is the core content of working capital management. Furthermore, due to spontaneous 
financing of non-human characteristics. The emphasize of working capital management of enterprise group's center of gravity will naturally fall on a short-term and long-term financing structure.

\section{The integration of assets}

There are several motives for mergers and acquisitions, some are due to operation hardship or in financial distress, or in order to reduce the financial risks, or the merger and acquisition take place when the target company have high quality assets in certain areas. No matter for what purpose, it is essential to integrate the two party's resources, particularly the target enterprise's assets.

Corporate assets are resources which are owned or controlled by enterprise, from past transactions or events and expected to bring economic benefits to the enterprise. Post-merger assets integration refers to category, cleaning, disposal, according to their quality and usage. And according to production needs, the assets are re-distributed in enterprise group interior after the acquisition and merger, so that the ratio of the enterprise's assets are properly managed. By integrating enterprise assets it can get a reasonable use of existing assets, improving its efficiency, to play its due functions.

The integration of main assets. Key assets integration:fixed assets are required bases for businesses to operate, also reflects the ability of enterprise production and management. Because of its great value and long service life, at the time of the integration fixed assets is the object of focus. According to the needs of the enterprises of the two parties assets can be swapped, reallocated, disposed, especially for the target enterprise assets. Fixed asset integration should take into account the following factors: the integrity of the production management system, namely, to ensure complete fixed asset needs for production and research. Strategic development plan of the enterprise, namely, the enterprise fixed assets scale and type should adapt to the development of the strategic development plan.

For those fixed assets which are not compatible with enterprise's overall development strategy, unable to generate economic benefits for a long time, excess administration fixed assets, or it can be used in the production but with low efficiency and high, and could not be accepted by both sides, it must be immediately disposed, picked out useful assets from all the assets. Enterprise's fixed assets using standards must be predetermined in order to make integration work smoothly, improve work efficiency and save money for businesses.

The integration of intangible assets:there are two kinds of intangible assets: productive intangible assets and market intangible assets. Productive intangible assets includes patents, know-how, production standards. Market intangible assets mainly refers to the business philosophy, corporate culture, product brands, trademarks, sales channels, and so on. Integration mainly covers a wide range of intangible asset including patents, proprietary technology, trademarks, franchises, land use rights and goodwill and so on. These intangible assets has the characteristics of non-entities, monotony, uncertainty, efficiency and creativity and so on. For the integration of intangible assets of the target enterprise, it is necessary to examine and assess the real value of these intangible assets, working closely with production and business activities of the acquirer and the appropriateness, its retention and transfer.

The integration of debts. In a stage of transition and integration of enterprise, the burden of indebtedness is shifted to other entities or debt into equity of the debtor, so as to adjust the debt ratio to a reasonable level, reduce the financial risks.

Debt restructuring can be achieved by external, can also be implemented through internal. External debt restructuring is mainly implemented through administrative relief for some or all of the debt, or through government matching funds, or through the company's large shareholders injecting capital. Internal debt restructuring is mainly through tap their own potentials, such as repay the debt by selling assets. Of course, this is without prejudice to the productivity of enterprises use. It can also use a way of debt-for-equity to relieve the pressure on corporate debt. Whether internal or external it need reach 
an agreement between the two parties of merger. Both parties need to make some compromises, then debt restructuring will be successful, ultimately minimizing the losses of the creditor and the debtor.

\section{Summary}

Financial integration plays an important role in enterprise mergers and acquisitions, it is the prerequisite and basis of success of merger and acquisition. Financial department must make integration measures, such as financial objectives, financial institutions, assets, debt and other aspects to ensure the full integration of financial resources, improve the efficiency of the financial management, provides a good foundation for the development of enterprise after the merger.

\section{References}

[1] Wang Xiaoying. Analysis on the Financial Coordination Effect for the Integration of Mergers and Acquisitions [M] . Journal of Fuzhou University.2010.2 .

[2] Gan Qinghua. The realization of financial integration effect after Mergers and Acquisitions [M]. Assets and Finance on Administrative unit. 2011.6.

[3] Bae, Kee-Hong, Jun-Koo Kang and Jin-Mo Kim. Tunneling or value added? Evidence from mergers by Korean business groups, Journal of Finance 2002， 57,2695-2740

[4] Capron L.\& Pistre, N. When do acquirers earn abnormal returns? Strategic Management Journal, 2002, (23) : 780-791.

[5] Yu Haozhou. Risk Management on Effective Integration after Mergers and Acquisitions [M] .Modern Economic Information. 2015.2.

[6] Hao Meiling. Analysis on the Financial synergy effect after Mergers and Acquisitions [M] . Metallurgical Economic and Management. 2011.2.

[7] Bruner. Does M\&A Pay? A Survey of Evidence for The Decision-Maker, Journal of Applied Finance, 2002, Spring / Summer: 48-68.

[8] Wang Huacheng. Advanced Financial Management. Beijing. 2011.8

[9] Agrawal A, Jaffe J. F. The Post-Merger Performance Puzzle[M]. Advances in Mergers and Acquisitions. 2000, (1): 741.

[10] Zuo Chunfang. Strategy on the financial integration after merger and acquisition [M]. China Commercial Trade. 2015.2. 